\title{
Study of Genetics Mutations in HEXA Gene for Induced Tay-Sachs Disease in Human, Tabriz, Iran
}

\section{Shahin A*, Mahsa J and Samaneh SD}

Young Researchers and Elite Club, Islamic Azad University, Iran

*Corresponding author: Shahin Asadi, Student of Molecular Genetics, Young

Researchers and Elite Club, Tabriz Branch, Islamic Azad University, Tabriz, Iran, Tel: +989379923364; E-mail: shahin.asadi1985@gmail.com

\section{Research Article}

Volume 2 Issue 1

Received Date: February 23, 2017

Published Date: March 08, 2017

DOI: $10.23880 /$ oajmb-16000113

\section{Abstract}

Tay-Sachs disease is one of the few neurodegenerative diseases of known causes. It results from mutations of the HEXA gene encoding the alpha subunit of beta-hexosaminidase, producing a destructive ganglioside accumulation in lysosomes, principally in neurons. With the determination of the protein sequence of the alpha and beta subunits, deduced from cDNA sequences, the complex pathway of sub cellular and lysosomal processing of the enzyme has been determined. More recently, detailed knowledge of the gene structure has allowed the determination of specific mutations causing TaySachs disease. The high incidence of the disease in Ashkenazi Jews is attributed predominantly to three mutations present in high frequency, while in non-Jews some two dozen mutations have been identified thus far. The cataloguing of mutations has important implications for carrier screening and prenatal diagnosis for Tay-Sachs disease.

Keywords: HEXA Gene; cDNA; Beta-Hexosaminidase; Tay-Sachs Disease

\section{Introduction}

Tay-Sachs disease (also known as GM2 gangliosidosis or hexosaminidase a deficiency) is a rare autosomal recessive genetic disease. In its most common allele, it causes a progressive deterioration of nerve cells and of mental and physical abilities that begins around 7 months of age and usually results in death by the age of four. The disease occurs when harmful quantities of cell membrane components known as gangliosides accumulate in the brain's nerve cells, eventually leading to the premature death of the cells. A ganglioside is a form of sphingolipid, which makes Tay-Sachs disease a member of the sphingolipidoses. There is no known cure or treatment [119].

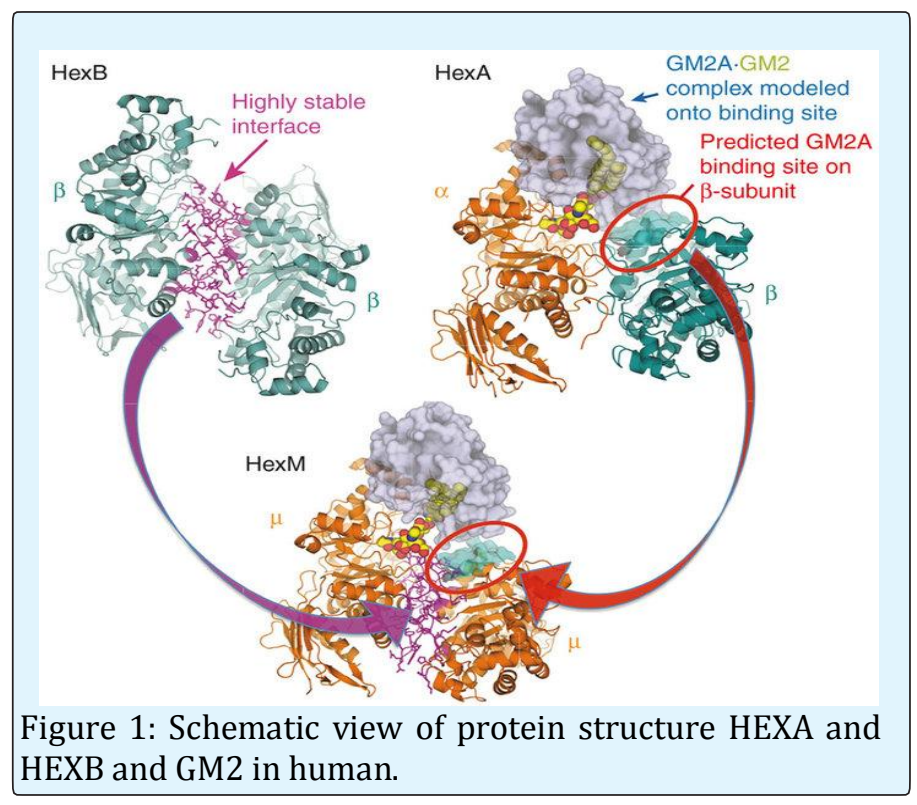

J Microbiol Biotechnol 


\section{Material and Methods}

In this study, 130 patients with Tay-Sachs disease and 300 healthy controls were studied. Peripheral blood samples from patients and parents with written permission control were prepared. After separation of serum, using Real Time-PCR technique of RNA molecules was collected. To isolate Neuroglial cells erythrocytes were precipitated from hydroxyethyl starch (HES) was used. At this stage, HES solution in ratio of 1 to 5 with the peripheral blood of patients and controls were mixed. After 60 minutes of incubation at room temperature, the supernatant was removed and centrifuged for $9 \mathrm{~min}$ at 200 Gera [20]. The cell sediment with PBS (phosphate buffered saline), pipetazh and slowly soluble carbohydrate ratio of 1to2 on ficole (Ficoll) was poured in the 500G was centrifuged for 24 minutes. Mono nuclear Neuroglial cells also are included, has a lower density than ficole and soon which they are based. The remaining erythrocytes have a molecular weight greater than ficole and deposited in test tubes [21-24].

The supernatant, which contained the mono nuclear cells, was removed, and the $300 \mathrm{G}$ was centrifuged for 12 minutes. Finally, the sediment cell, the antibody and Neuroglial cells was added after 34 minutes incubation at $5^{\circ} \mathrm{C}$, the cell mixture was passed from pillar HEXA. Then the cells were washed with PBS and attached to the column HEXA pam Stem cell culture medium containing the transcription gene HEXA and were kept [23].

To determine the purity of Neuroglial cells are extracted, flow cytometry was used. For this purpose, approximately 8-9 $\times 10^{4}$ Neuroglial cells were transfer red to $1.5 \mathrm{ml}$ Eppendorf tube and then was centrifuged at 2000 rpm for 7 minutes at time. Remove the supernatant culture medium and there maining sediment, $100 \mu \mathrm{l}$ of PBS buffer was added. After adding 5-10 $\mu$ l CD38 ${ }^{+}$PE monoclonal anti body to the cell suspension for $60 \mathrm{~min}$ at $4{ }^{\circ} \mathrm{C}$, incubated and read immediately by flow cytometry Technique. For example, rather than control anti body Neuroglial cells PE, IgG1 negative control solution was used [22].

\section{Total RNA Extraction Procedure Includes}

$2 \mathrm{ml}$ solution spilled Qiazolon cells, and slowly and carefully mixed and incubated at room temperature for 5 minutes. Then $100 \mu \mathrm{l}$ chloroform solution to target mix, then transfer the micro tubes were added, and the shaker well was mixed for 15 seconds. The present mix for 4 minutes at room temperature and then incubated for 20 min at $5^{\circ} \mathrm{C}$ an was centrifuged at $13200 \mathrm{rpm}$ era. Remove the upper phase products were transferred to a new microtube and to the one times the volume of cold ethanol were added. The resulting mixtures for 24 hours at $-20^{\circ} \mathrm{C}$ were incubated [25].

Then for $55 \mathrm{~min}$ at $5^{\circ} \mathrm{C}$ was centrifuged at $12800 \mathrm{rpm}$ era. Remove the supernatant and the white precipitate, $1 \mathrm{ml}$ of cold $75 \%$ ethanol was added to separate the sediment from micro tubes were vortex well. The resulting mixture for $20 \mathrm{~min}$ at $5^{\circ} \mathrm{C}$ by the time we were centrifuged $12800 \mathrm{rpm}$. Ethanol and the sediment was removed and placed at room temperature until completely dry deposition. The precipitate was dissolved in $20 \mu \mathrm{l}$ sterile water and at a later stage, the concentration of extracted RNA was determined [26-30].

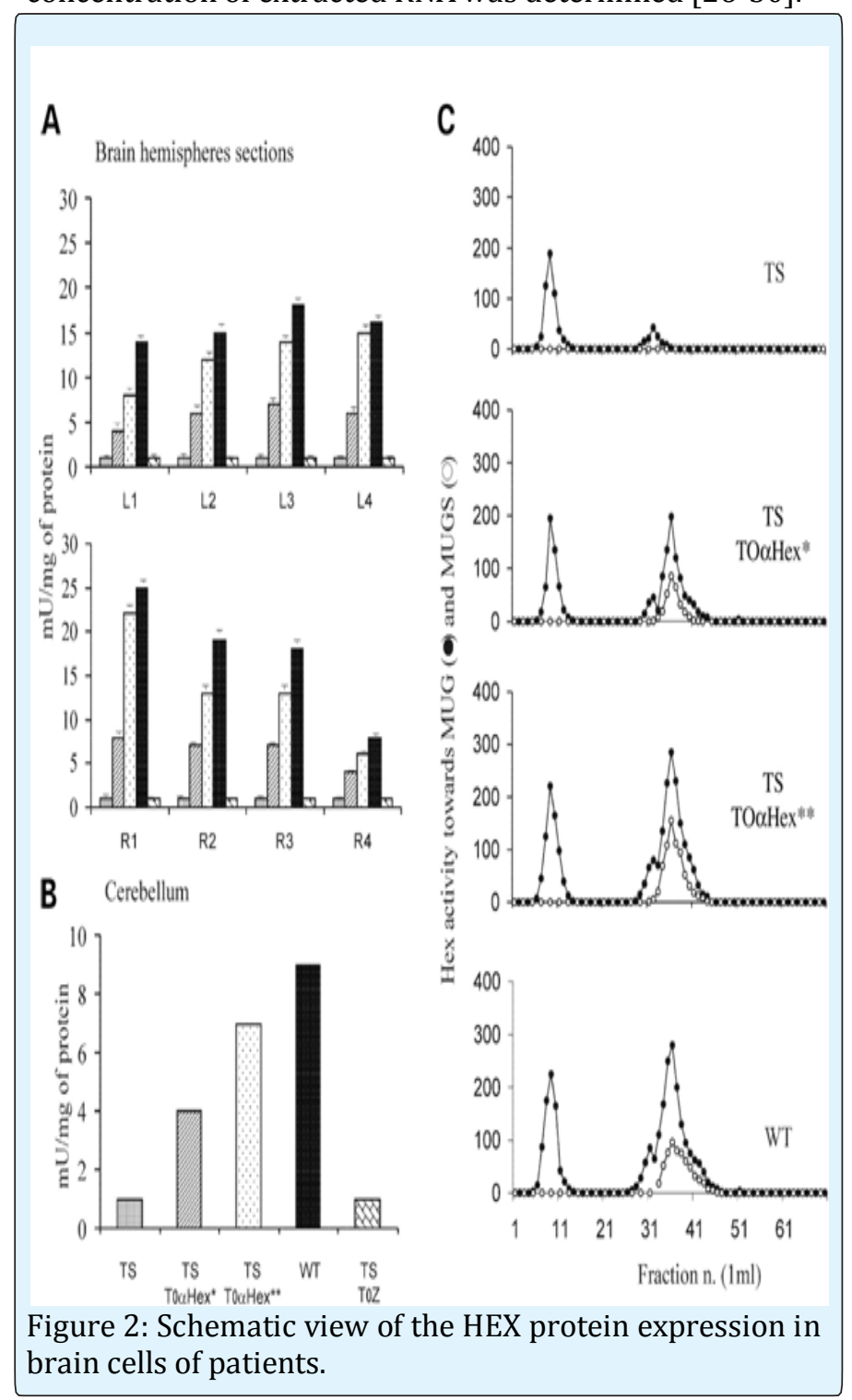



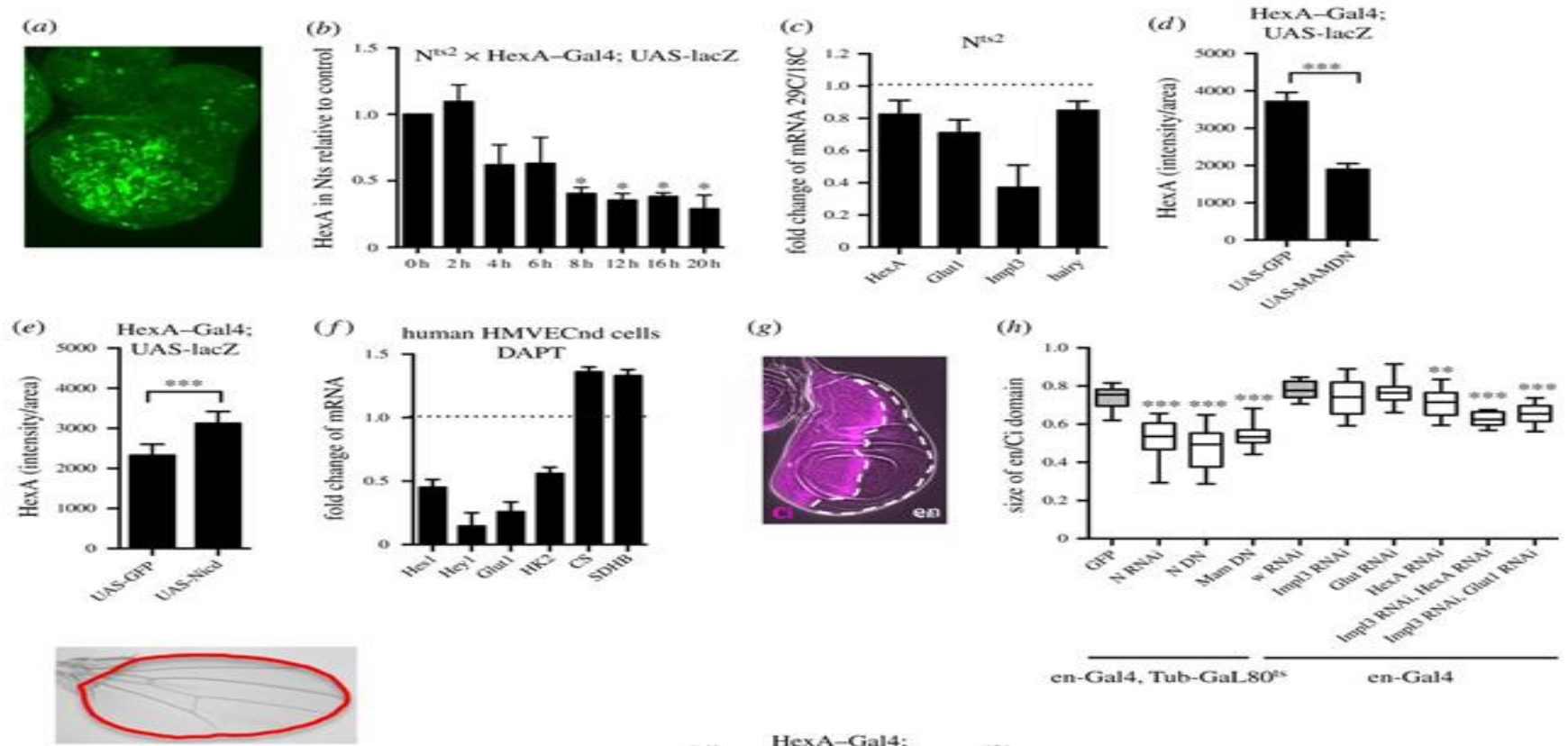

en-Gal4, Tub-GaLsoss en-Gal4
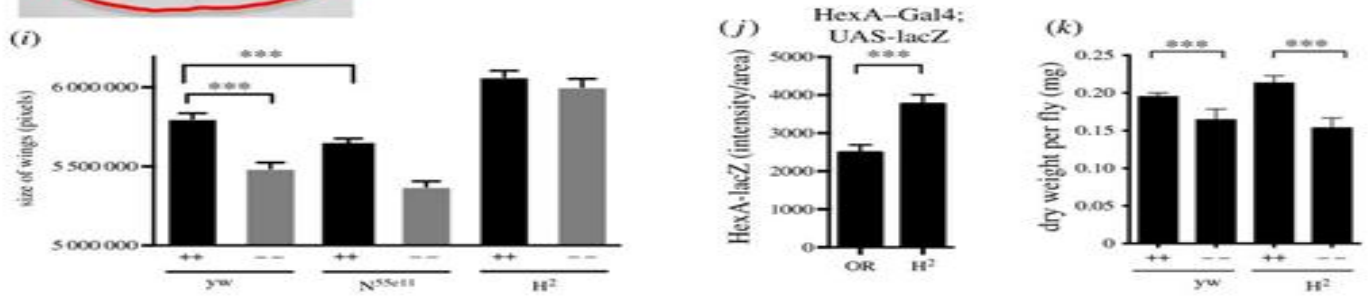

Figure 3: Schematic view of linear and microscopic HEXA protein expression level in the brain cells of patients.
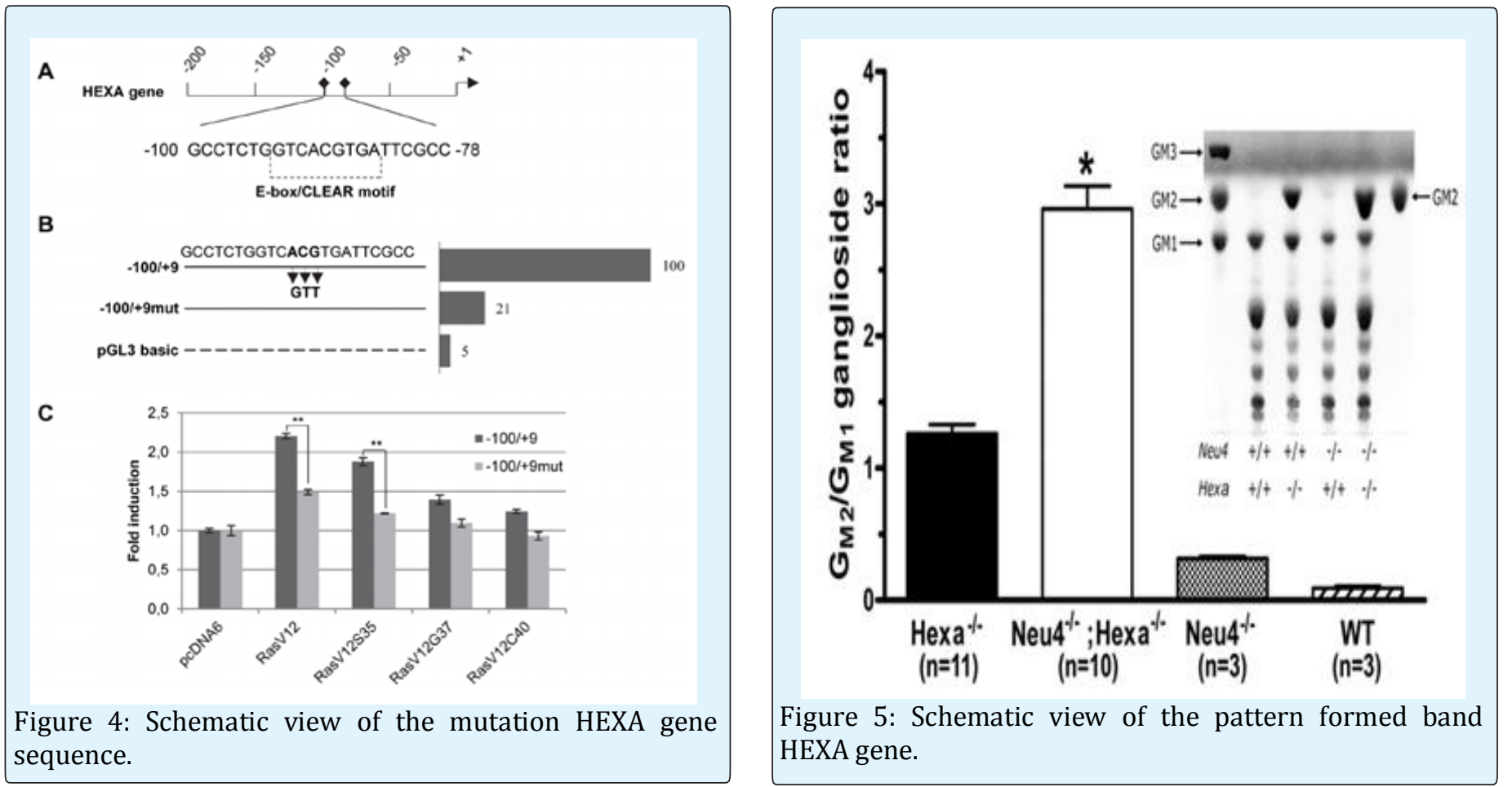


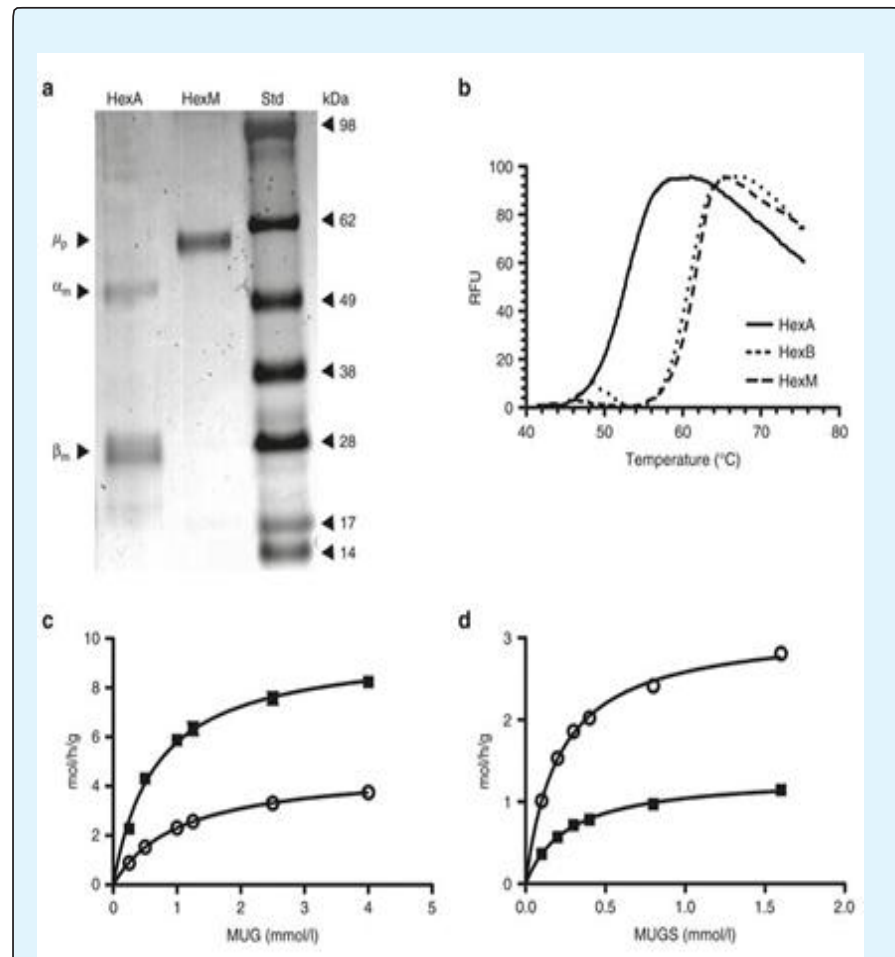

Figure 6: Schematic view of denaturing HEXA gene.

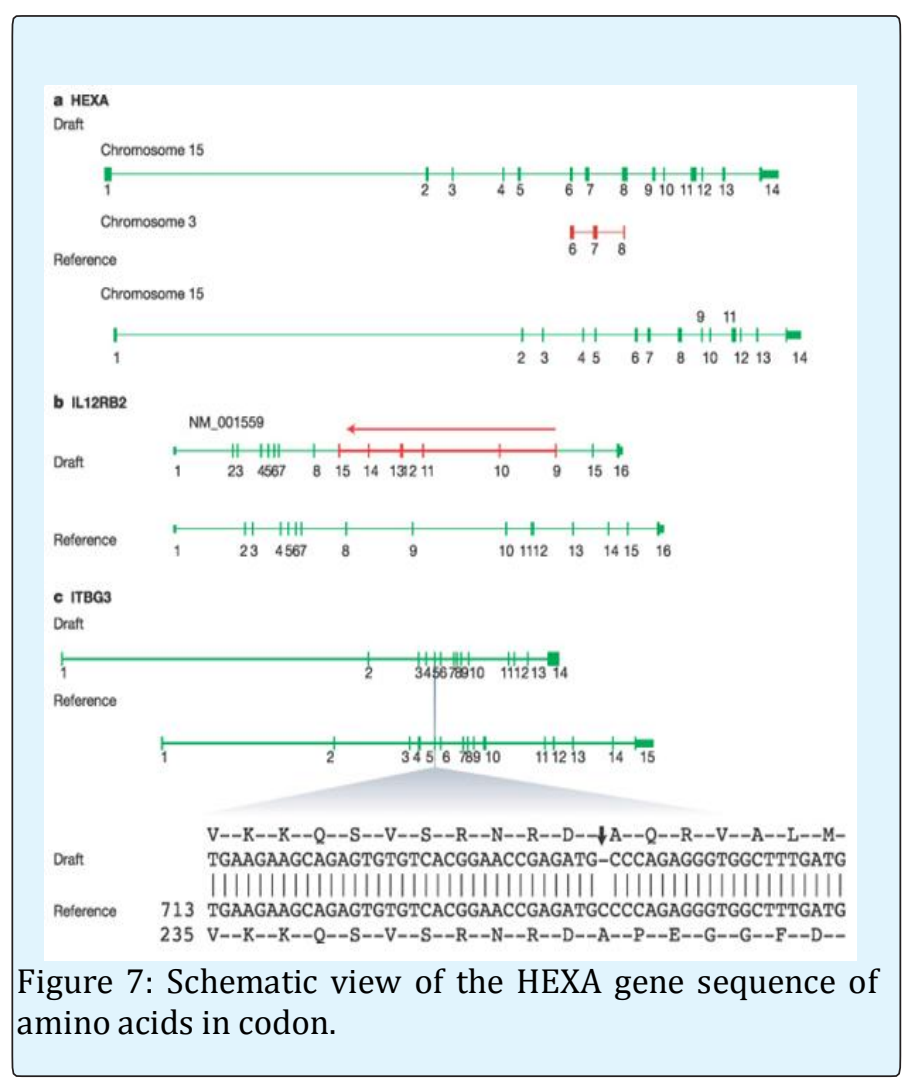

\section{HEXA protein domain}
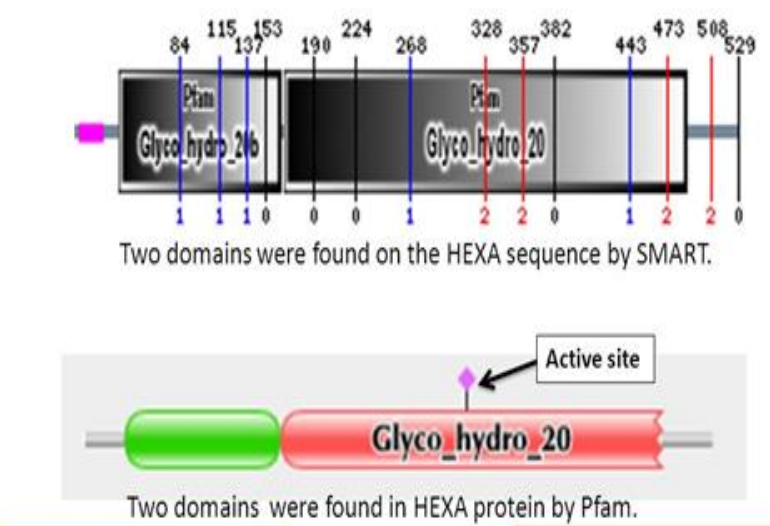

Glycoside hydrolase family 20 ,

domain 2

Glycoside hydrolase family 20 , catalytic domain

ABNORMAL BREAKDOWN OF GM2 GANGLIOSIDE IN TAY-SACHS DISEASE

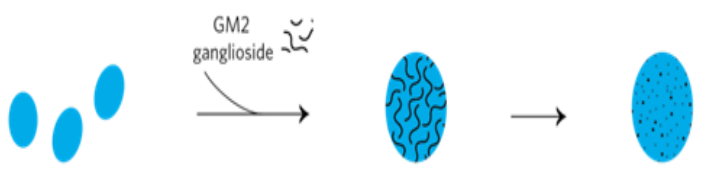

Lysosomes contain enzymes

(like Hex A) that break down

GM2 ganglioside compounds in the body is broken down

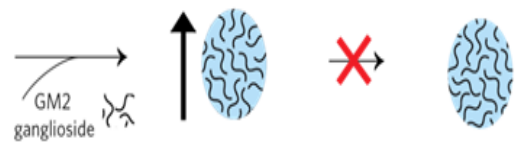

In people with Tay-Sachs disease, the Hex A enzymes in the lysosomes

do not function properly

GM2 ganglioside cannot GM2 ganglioside
be broken down properly is not broken down
and accumulates
in the brain

Figure 8: Schematic view of abnormal breakdown of GM2 ganglioside in Tay-Sachs disease.

\section{Discussion and Conclusion}

According to the results of sequencing the genome of patients with Tay-Sachs disease, and the genetic mutations HEXA gene found that about $100 \%$ of patients with Tay-Sachs disease, they have these genetic mutations. Patients with Tay-Sachs disease, unusual and frightening images in the process of Tay-Sachs disease, experience. Lot epigenetic factors involved in Tay-Sachs disease. But the most prominent factor to induce TaySachs disease, mutations is HEXA gene. This gene can induce the birth and can also be induced in the adulthood. 


\section{Open Access Journal of Microbiology \& Biotechnology}

\section{Acknowledgments}

Thanks to everyone who helped us in doing this project, very grateful. Patients and their families also accept patients who had very much for your cooperation in this study.

\section{References}

1. Lewis, Ricki (1997) Human Genetics. Wm. C. Brown, Chicago, IL: pp. 247-248.

2. Mc Kusick, Victor A, Hamosh, Ada (2009) Online Mendelian Inheritance in Man. United States National Institutes of Health.

3. Specola N, Vanier MT, Goutières F, Mikol J, Aicardi J (1990) The juvenile and chronic forms of GM2 gangliosidosis: clinical and enzymatic heterogeneity. Neurology 40(1): 145-150.

4. Moe PG, Benke TA (2005) Neurologic and Muscular Disorders. Current Pediatric Diagnosis and Treatment (17 ed) McGraw-Hill.

5. Rosebush PI, Mac Queen GM, Clarke JT, Callahan JW, Strasberg PM, et al. (1995) Late-onset Tay-Sachs disease presenting as catatonic schizophrenia: Diagnostic and treatment issues. J Clin Psychiatry 56(8): 347-353.

6. Willner JP, Grabowski GA, Gordon RE, Bender AN, Desnick RJ (1981) Chronic GM2 gangliosidosis masquerading as atypical Friedreich's ataxia: clinical, morphologic, and biochemical studies of nine cases. Neurology 31(7): 787-798.

7. Myerowitz R (1997) Tay-Sachs disease-causing mutations and neutral polymorphisms in the Hex A gene. Hum Mutat 9(3): 195-208.

8. Keats BJ, Elston RC, Andermann E (1987) Pedigree discriminant analysis of two French Canadian TaySachs families. Genet Epidemiol 4(2): 77-85.

9. De Braekeleer M, Hechtman P, Andermann E, Kaplan F (1992) The French Canadian Tay-Sachs disease deletion mutation: Identification of probable founders. Hum Genet 89(1): 83-87.

10. Kaback MM, Desnick RJ (2011) Hexosaminidase A Deficiency. In: Pagon RA, et al. GeneReviews [Internet]. Seattle, Washington, USA: University of Washington, Seattle.
11. Mahuran DJ (1999) Biochemical consequences of mutations causing the GM2 gangliosidoses. Biochim Biophys Acta 1455(2-3): 105-138.

12. Hechtman P, Kaplan F (1993) Tay-Sachs disease screening and diagnosis: evolving technologies. DNA Cell Biol 12(8): 651-665.

13. Aragão RE, Ramos RM, Pereira FB, Bezerra AF, Fernandes DN (2009) 'Cherry red spot' in a patient with Tay-Sachs disease: case report. Arq Bras Oftalmol 72(4): 537-539.

14. Stoller D (1997) Prenatal Genetic Screening: the enigma of selective abortion. J Law Health 12(1): 121140.

15. Bodurtha J, Strauss JF (2012) Genomics and perinatal care. N Engl J Med 366(1): 64-73.

16. Ekstein J, Katzenstein H (2001) The Dor Yeshorim story: community-based carrier screening for TaySachs disease. Adv Genet 44: 297-310.

17. Eeg-Olofsson L, Kristensson K, Sourander $P$, Svennerholm L (1966) Tay-Sachs disease A generalized metabolic disorder. Acta Paediatrica Scand 55(6): 546-562.

18. Shapiro BE, Hatters-Friedman S, Fernandes-Filho JA, Anthony K, Natowicz MR (2006) Late-onset TaySachs disease: Adverse effects of medications and implications for treatment. Neurology 67(5): 875877.

19. Clarke JT, Mahuran DJ, Sathe S, Kolodny EH, Rigat BA, Raiman JA, Tropak MB (2004).

20. Rozenberg R, Pereira Lda V (2001) The frequency of Tay-Sachs disease causing mutations in the Brazilian Jewish population justifies a carrier screening program. Sao Paulo Med J 119(4): 146-149.

21. Frisch A, Colombo R, Michaelovsky E, Karpati M, Goldman B, et al. (2004) Origin and spread of the 1278insTATC mutation causing Tay-Sachs disease in Ashkenazi Jews: genetic drift as a robust and parsimonious hypothesis. Hum Genet 114(4): 366376.

22. Koeslag JH, Schach SR (1984) Tay-Sachs disease and the role of reproductive compensation in the maintenance of ethnic variations in the incidence of autosomal recessive disease. Ann Hum Genet 48(3): 275-281. 
23. The Jewish Encyclopedia (2011) New York: Funk and Wagnalls 1901-1906.

24. Okada S, O'Brien JS (1969) Tay-Sachs disease: generalized absence of a beta-D-N-acetyl hexosaminidase component. Science 165(3894): 698700.

25. O'Brien JS, Okada S, Chen A, Fillerup DL (1970) TaySachs disease: Detection of heterozygotes and homozygotes by serum hexaminidase assay. $\mathrm{N}$ Engl J Med 283(1): 15-20.

26. Sagi M (1998) Ethical aspects of genetic screening in Israel. Sci Context 11(3-4): 419-429.
27. Kimura M (1983) The Neutral Theory of Molecular Evolution. Cambridge: Cambridge University Press.

28. Matsuoka K, Tamura T, Tsuji D, Dohzono Y, Kitakaze $\mathrm{K}$, et al. (2011).

29. Torres PA, Zeng BJ, Porter BF, Alroy J, Horak F, et al. (2010) Tay-Sachs disease in Jacob sheep". Mol Genet Metab 101(4): 357-363.

30. Porter BF, Lewis BC, Edwards JF, Alroy J, Zeng BJ, et al. (2011) Pathology of GM2 Gangliosidosis in Jacob Sheep. Veterinary Pathology 48(3): 807-813.

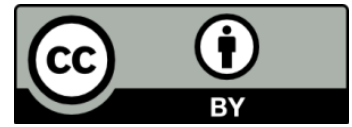

